\title{
ANALISIS TINDAK TUTUR REPRESENTATIF DALAM PODCAST DEDDY CORBUZIER DENGAN NADIEM MAKARIM-KULIAH TIDAK PENTING?
}

\author{
${ }^{1}$ Adriesty Salma Lailika, ${ }^{2}$ Asep Purwo Yudi Utomo \\ ${ }^{1}$ Universitas Negeri Semarang, adriesty_salmal31@students.unnes.ac.id \\ ${ }^{2}$ Universitas Negeri Semarang, aseppyu@ mail.unnes.ac.id
}

\begin{abstract}
Language is used as a tool to convey messages from speakers to speech partners (spoken language) or from writers to readers (written language), language is a communication tool. Activities that perform speech acts are called speech acts. Of a number of criteria, there are several types of speech acts, one of which is representative speech act. The speech is interesting and the writer studies pragmatically the speech contained in the Deddy Corbuzier podcast with Nadiem Makarim-Lectures Not Important?.The purpose of this study is: (1) Describe the forms of representative speech acts from Deddy Corbuzier podcast with Nadiem Makarim. Lectures Are Not Important? -College Not Important? The object from this research is the dialogue of Representative Speech Acts Deddy Corbuzier with Nadiem Makarim-Lectures Not Important. Data Sources in this study are oral data sources from Dedy Corbuzier's youtube channel, Dedy Corbuzier's dialogue in a podcast with Nadiem Makarim-Lectures Not Important. The approach used in this research is pragmatic approach and qualitative descriptive approach.. The data collection techniques using free listening techniques and use note taking techniques. The data analysis method uses the matching method, while for the method of presenting the results of data analysis in the form of an informal method. The speech strategy used tends to be biased towards the direct speech act strategy. From this research, the writer hopes to find meaning or purpose in a podcast that will later be useful and used for reference in life by the reader.. From the video duration of 10 minutes 56 seconds the results of this study contain 16 data including representative speech acts.
\end{abstract}

Keyword(s): Language, pragmatics, speech acts, podcasts, representative speech acts

\begin{abstract}
ABSTRAK
Bahasa digunakan sebagai alat yang berfungsi untuk menyampaikan pesan dari penutur kepada mitra tutur (bahasa lisan) atau dari penulis kepada pembaca (bahasa tulis), bahasa merupakan alat komunikasi. Kegiatan yang melakukan tindakan tuturan ini disebut dengan tindak tutur. Atas beberapa kriteria, ada 15 jenis tindak tutur, salah satunya tindak tutur representatif. Tuturan tersebut menarik dan penulis kaji secara pragmatik merupakan tuturan yang terdapat dalam podcast Deddy Corbuzier dengan Nadiem Makarim-Kuliah Tidak Penting?. Penelitian ini bertujuan untuk: (1) Mendeskripsikan bentuk tindak tutur representatif yang terdapat dalam
\end{abstract}


podcast Deddy Corbuzier dengan Nadiem Makarim-Kuliah Tidak Penting?, (2) Mendeskripsikan maksud tuturan tindak tutur representatif dalam tindak tutur representatif yang terdapat pada podcast Deddy Corbuzier dengan Nadiem Makarim-Kuliah Tidak Penting?Objek penelitian ini berupa dialog tindak tutur representatif podcast Deddy Corbuzier dengan Nadiem Makarim-Kuliah Tidak Penting. Sumber data dalam penelitian ini berupa sumber data lisan dari channel youtube Dedy Corbuzier, dialog Dedy Corbuzier dalam podcast dengan Nadiem Makarim-Kuliah Tidak Penting. Pendekatan penelitian ini berupa pendekatan pragmatik dan pendekatan deskriptif kualitatif. Teknik pengumpulan data menggunakan teknik simak bebas dan teknik catat. Metode analisis data berupa metode padan, sedangkan metode penyajian hasil analisis data menggunakan metode informal. Strategi tuturan yang digunakan cenderung condong ke dalam strategi tindak tutur langsung. Dari penelitian ini, diharapkan dapat menemukan makna dalam sebuah podcast yang akan berguna dengan referensi dalam kehidupan. Dari durasi video 10 menit 56 detik hasil penelitian ini memuat 16 data yang termasuk tindak tutur representatif.

Kata kunci: Bahasa, pragmatik, tindak tutur, siaran serial, tindak tutur representatif.

\section{How to Cite:}

Lailika, Adriesty Salma \& Asep Purwo Yudi Utomo. (2020). Analisis Tindak Tutur Representatif dalam Podcast Deddy Corbuzier Dengan Nadiem Makarim-Kuliah Tidak Penting ? Bahtera Indonesia: Jurnal Penelitian Pendidikan Bahasa dan Sastra Indonesia, Vol. 5, No. 2, 97-109.

DOI: https://doi.org/10.31943/bi.v5i2.70

\section{PENDAHULUAN}

Bahasa digunakan sebagai alat yang berfungsi untuk menyampaikan pesan dari penutur kepada mitra tutur (bahasa lisan) atau dari penulis kepada pembaca (bahasa tulis), bahasa merupakan alat komunikasi. Berkomunikasi merupakan kebutuhan setiap manusia, tentunya bergantung pada lingkungan dan manusia itu sendiri, manusia berperan sebagai lawan tutur. Tindak tutur yaitu alat untuk melakukan komunikasi dan bagian yang sangat erat, berkaitan dengan pragmatik.
Wijana (1996:1) berpendapat pragmatik merupakan cabang ilmu bahasa yang mempelajari struktur bahasa secara eksternal, yakni bagaimana kesatuan bahasa itu digunakan dalam komunikasi. Leech (1993: 5-6) pragmatik mempelajari maksud ujaran yaitu untuk apa ujaran itu dilakukan: menanyakan apa yang seseorang maksud dengan suatu tindak tutur dan mengaitkan makna dengan siapa berbicara pada siapa, dimana, bilamana, bagaimana. Pragmatik membahas maksud tuturan terikat dengan konteks tutur. 
Tindak tutur adalah analisis bidang pragmatik, merupakan cabang ilmu bahasa yang mengkaji bahasa dari aspek pemakaian bahasa (maksud tuturan). Tindak tutur menurut Chaer (2010: 27) dalam bukunya berpendapat, tindak tutur adalah tuturan dari seseorang yang bersifat psikologis dan yang dilihat dari makna tindakan dalam tuturannya itu. Peristiwa tutur yaitu serangkaian tindak tutur yang terjadi.

Tidak tutur atas sejumlah kriteria, ada beberapa jenis, salah satunya tindak tutur representatif. Salah satu tuturan yang menarik, dan sangat layak penulis kaji secara pragmatik adalah tuturan yang dalam podcast Deddy Corbuzier dengan Nadiem MakarimKuliah Tidak Penting? Salah satu media untuk menganalisis tindak tutur adalah melalui podcast.

Pada zaman sekarang ini, podcast sudah banyak digunakan. Berasal dari kata "pod" dan "broadcasting", Podcast adalah sebuah media yang telah teruji selama beberapa tahun dan sekarang sedang bergerak menuju periode kredibilitas, stabilitas, dan kematangan (Berry, 2016). Podcast sebenarnya sudah sangat populer di Amerika Serikat dan beberapa negara lainnya. Namun, di Indonesia, popularitas podcast memang belum tinggi layaknya media on-demand serupa seperti musik dan video. Namun, akhir-akhir ini podcast mendapatkan daya tarik yang sangat pesat. Karena itu saya mencoba menganalisis tindak tutur representatif dalam podcast Deddy Corbuzier dengan Nadiem Makarim-Kuliah Tidak Penting?. Seperti yang kita ketahui bersama akun youtube Deddy Corbuzier bisa dibilang sangat terkenal dengan podcastnya yang sangat inspiratif. Per bulan Mei 2020 tercatat Deddy memiliki 9,2 juta subscriber. Hal-hal tersebut yang menarik minat penulis menganalisis video podcast Deddy Corbuzier.

Kegiatan mengujarkan suatu tuturan itulah yang disebut dengan tindak tutur. Atas beberapa kriteria, ada 15 jenis tindak tutur, yaitu : (1) tindak tutur konstatif, (2) performatif, (3) lokusi, (4) ilokusi, (5) perlokusi, representatif atau asertif, (6) direktif, (7) ekspresif atau evaluatif, (8) komisif, (9) deklarasi atau establisif atau isbati, (10) langsung, (11) tidak langsung, (12) langsung harafiah, (13) langsung tidak harafiah, (14) tidak langsung harafiah, dan (15) tidak langsung tidak harafiah (Rustono, 1999:31). Untuk itu, kajian ini saya fokuskan kepada tindak tutur representatif atau asertif. Menurut Rustono, (1999:31) kegiatan melakukan tindakan mengujarkan tuturan itulah yang merupakan tindak tutur. Menurut Rustono, (1999:38) dalam bukunya menjelasakan, tindak tutur representatif adalah tindak tutur yang mengikat penuturnya akan kebenaran atas apa yang diujarkannya. Beberapa penelitian sebelumnya juga 
menganalisis tindak tutur representatif ini. Menurut Rustono, (1999:31) kegiatan melakukan tindakan mengujarkan tuturan itulah yang merupakan tindak tutur.

Beberapa penelitian yang berkaitan dengan tindak tutur representatif atau assertif telah diteliti oleh Yusri, dkk (2012) berjudul Representasi Tindak Tutur Calon Gubernur Sulawesi Selatan: Analisis Wacana Kesopanan Berbahasa; Zulfira Hildana R (2013) berjudul Tindak Tutur Ilokusi Representatif dalam Komik Seratoes Ploes Aspirasi Karya Haryadhi: Sebuah Kajian Pragmatik; Novi Safriani, dkk (2018) berjudul Tindak Tutur Asertif Dalam Novel Perempuan Terpasung Karya Hani Naqshabandi.

Dari beberapa penelitian tersebut, saya berpegang pada penelitian Zulfira Hildana R (2013) berjudul Tindak Tutur Ilokusi Representatif dalam Komik Seratoes Ploes Aspirasi Karya Haryadhi: Sebuah Kajian Pragmatik. Terdapat persamaan dan perbedaan terhadap penelitian yang dilakukan. Persamaannya yaitu meneliti tentang tindak tutur representatif. Sedangkan, perbedaannya terletak pada fokus penelitian, penulis hanya meneliti tindak tutur representatif, tidak mengkaji tindak tutur ilokusinya.

Berdasarkan latar belakang masalah di atas, maka rumusan masalahnya adalah: (1) bagaimana deskripsi bentuk tuturan tindak tutur representatif dalam podcast Deddy Corbuzier dengan Nadiem Makarim-Kuliah Tidak Penting?, (2) bagaiamana deskripsi maksud tuturan yang termasuk ke dalam tuturan tindak tutur representatif dalam podcast Deddy Corbuzier dengan Nadiem Makarim-Kuliah Tidak Penting?

Tujuan penulis melakukan penelitian ini adalah: (1) mendeskripsikan bentuk tuturan tindak tutur representatif dalam podcast Deddy Corbuzier dengan Nadiem Makarim-Kuliah Tidak Penting?, (2) mendeskripsikan maksud tuturan tindak tutur representatif dalam dalam podcast Deddy Corbuzier dengan Nadiem Makarim-Kuliah Tidak Penting?

\section{METODOLOGI PENELTIAN}

Pendekatan yang digunakan dalam penelitian ini berupa pendekatan pragmatik dan pendekatan deskriptif kualitatif. Penelitian ini difokuskan untuk mendeskripsikan bentuk dan maksud tindak tutur representatif dalam podcast Deddy Corbuzier dengan Nadiem Makarim-Kuliah Tidak Penting?.

Sumber data yang penulis gunakan dalam penelitian ini adalah video podcast Deddy Corbuzier dengan Nadiem MakarimKuliah Tidak Penting? Pada channel youtube Deddy Corbuzier yang diunggah pada tanggal 8 Maret 2020.

Hasil penelitian ini yakni tuturan yang mengandung tindak tutur representatif yang 
digunakan yakni: tuturan-tuturan

menyatakan, (2) menuntut, (3) mengakui, (4)

melaporkan,

(5) menunjukkan,

menyebutkan, (7) memberikan, (8) kesaksian,

(9) berspekulasi. Tuturan yang digunakan yaitu tindak tutur langsung pada podcast Dedy Corbuzier dengan Nadiem MakarimKuliah Tidak Penting?

Deskriptif disini berarti penulisan penelitian ini dilakukan berdasarkan fakta atau fenomena pada penuturny sehingga data yang dihasilkan benar apa adanya. Cara pengumpulan data yang dilakukan dalam penelitian ini dengan menggunakan padan. Metode analisis data berupa metode padan, yaitu metode yang mengidentifikaasi kebahasaan berdasarkan respon mitra tutur. Sedangkan metode penyajian hasil analisis data menggunakan metode informal yang nantinya hasil tidak seratus persen menggunakan bahasa baku. Teknik pengumpulan data menggunakan teknik simak bebas libat cakap dan teknik catat. Caranya yaitu dengan mendengarkan dan mencatat keseluruhan percakapan dalam podcast tersebut. Penelitian ini dimulai dari mendengarkan dengan seksama isi podcast dilanjutkan dengan pencatatan data dialog dalam podcast

\section{HASIL DAN PEMBAHASAN}

Hasil dalam penelitian ini mencakup dua hal yang sesuai dengan rumusan masalah dan tujuan penelitian yang dibahas di atas, yaitu (1) deskripsi bentuk tindak tutur representatif dalam podcast Deddy Corbuzier dengan Nadiem Makarim-Kuliah Tidak Penting?, (2) deskripsi maksud yang terdapat pada tindak tutur representatif dalam podcast Deddy Corbuzier dengan Nadiem MakarimKuliah Tidak Penting?

\section{Menyatakan}

Dalam penelitian ini, tindak tutur represesntatif menyatakan memiliki sifat subyektif karena si penutur menyampaikan informasi berdasarkan pengertiannya atau pemahamannya terhadap suatu informasi kepada mitra tutur. Dimana dalam penelitian sebelumnnya menganalisis tindak tutur ilokusi representatif. Berikut ini, merupakan hasil dan pembahasan tindak tutur representatif menyatakan dalam podcast Dedy Corbuzier dengan Nadiem MakarimKuliah Tidak Penting?

(1) Deddy: "Ini gua baru bikin buku, now it's top 10 book, judulnya adalah "Milenial Power Rahasia Milenial Kaya dan Mandiri"

Konteks Tutur: tuturan tersebut dituturkan oleh Deddy secara lisan dalam awal podcast. Tuturan tersebut berfungsi menjelaskan judul buku Deddy yang masuk top 10 sekarang. 
Tuturan di atas termasuk 'menyatakan' karena tuturannya menyatakan sesuatu yang memaksa mitra tutur percaya dengan apa yang dinyatakan oleh penutur.

(2) Deddy :'Jadi gue mau mengatakan kuliah penting nggak ya? Dan disini banyak sekali gua ngomong tentang betapa tidak pentingnya pelajaran di sekolah."

Konteks Tutur: tuturan tersebut dituturkan oleh Deddy secara lisan dalam awal podcast. Argumen ke-2 Deddy.

Tuturan tersebut berfungsi mendukung penjelasan Deddy sebelumnya, tentang judul buku yang masuk top-10. Deddy menjelaskan bagian awal buku tersebut berisi alasan-alasan argumennya betapa tidak pentingnya pelajaran di sekolah. Tuturan di atas termasuk 'menyatakan' karena menyatakan sesuatu yang yang memaksa mitra tutur percaya dengan apa yang dinyatakan oleh penutur.

(3) Nadiem :"Salah satu hal yang mau kita bikin adalah pusat penguatan karakter, yang sebenarnya setengah pendidikan setengah revolusi mental."

Konteks Tutur: tuturan tersebut dituturkan oleh Nadiem secara lisan dalam podcast. Untuk menyanggah statement Deddy bahwa kuliah atau sekolah "tidak penting". Karena menurut Nadiem kuliah dan sekolah adalah penting.

Tuturan tersebut berfungsi menyanggah pernyataan Deddy yang berpendapat bahwa kuliah atau sekolah "tidak penting", sedangkan menurut Nadiem kuliah dan sekolah adalah penting. Nadiem menyanggah argumen Deddy dengan menjelaskan betapa pentingnya sekolah, dalam Kemendikbud, sekolah yang dimaksud adalah sekolah formal, dengan gebrakan akan membuat pusat penguatan karakter. Tuturan di atas termasuk 'menyatakan' sesuatu yang memaksa mitra tutur percaya dengan apa yang dinyatakan oleh penutur.

\section{Menuntut}

Tindak tutur representatif menuntut, dituturkan oleh penutur memiliki sifat lebih memaksa dan harus dituruti oleh mitra tutur.

(1) Nadiem: "Jadi kuliah merdeka, mereka berada di luar prodi yang kita lakukan itu sangat penting, ini kebijakan yang dibutuhkan, karena komunitas profit non profit dunia perusahaan dan juga universitas-universitas lain harus berpartisipasi untuk melatih si-S1 ini”.

Konteks Tutur: tuturan tersebut dituturkan oleh Nadiem untuk menguatkan argumen sebelumya tentang topik 'Kuliah Merdeka'.

Tuturan tersebut yaitu tuntutan Nadiem yang menekankan bahwa "Kuliah Merdeka" itu penting, berfungsi untuk menguatkan argumen-argumen sebelumnya, menekankan/menuntut Deddy tentang seberapa pentingnya Kuliah Merdeka. Tuturan ini termasuk kedalam tindak tutur representatif menuntut. 
(2) Nadiem: "Saya nggak setuju sama Mas Deddy, bahwa itu, dengan statement bahwa "Tidak penting" Menurut saya penting, seberapa pentingnya tergantung pada apa yang terjadi dalam unit pendidikan itu."

Konteks Tutur: tuturan tersebut dituturkan oleh Nadiem untuk menyanggah argumen Deddy sebelumnya.

Tuturan tersebut yaitu tuntutan Nadiem yang menekankan bahwa ia tidak setuju dengan argumen Deddy dan menyanggahnya dengan argumen-argumen tersebut. Tuturan ini termasuk kedalam tindak tutur representatif menuntut.

(3) Nadiem :"'Itu yang bagus-bagus misalnya seperti perusahaan sebelum saya, yang terhebat-hebat lulusan-lulusan kampuskampus itu bukan yang IPK-nya tertinggi, yang terhebat-hebat itu biasannya IPK-nya lebih turun, kita yang nyarinya yang disekitar 3 . Kenapa nyari yang disekitar 3, karena disitu experience atau pengalaman kepemimpinannya dia tu sangat tinggi, dia berbagai macam olah aktivitas, dari BEM ngatur-ngatur IO, dari situlah kepemimpinannya terjaga."

Konteks Tutur: tuturan tersebut dituturkan oleh Nadiem dalam podcast.

Tuturan tersebut terlihat Nadiem menekan Deddy supaya percaya dengan pendapatnya. Bahwa IPK tinggi biasanya tidak memiliki softskill karena jarang ikut organisasi kemahasiswaan. Tuturan tersebut termasuk dalam tindak tutur representatif menuntut, menuntut mitra tutur setuju dengan argumen si penutur.

\section{Mengakui}

Tindak tutur representatif mengakui yang dituturkan penutur memiliki sifat tidak akurat, karena merupakan asumsi pribadi penutur, pandangan personal si penutur.

(1) Deddy: "Waktu gua denger lu yang jadi Menteri Pendidikan baru, I say that with my family waktu itu, its good, bagus lu yang jadi Menteri Pendidikan, gua suka cara berpikiran lu".

Konteks Tutur: dituturkan oleh Deddy secara lisan dalam podcast untuk menyanggah argumen Nadiem.

Tuturan tersebut berfungsi menjelaskan, bahwa Deddy mengakui Nadiem baik untuk tataran Menteri Pendidikan, bagus idenya dalam mengubah pendidikan di Indonesia.

(2) Deddy :"Yes, I like this, I like your argumennt."

Konteks Tutur: tuturan tersebut dituturkan oleh Deddy secara lisan dalam podcast untuk menimpali argumen Nadiem.

Tuturan tersebut berfungsi menjelaskan, bahwa Deddy mengakui argumen Nadiem

(3) Deddy :"I think I agree with your opinion, gua ngomong "jadi apakah kuliah itu penting? Terus gue bilang, ya penting." 
Konteks Tutur: tuturan tersebut dituturkan oleh Deddy secara lisan dalam podcast untuk menyetujui argumen Nadiem.

Tuturan tersebut berfungsi menjelaskan, bahwa Deddy mengakui argumen Nadiem dan akhirnya Deddy mengakui bahwa kuliah itu penting.

(4) Deddy :"Nah bro gua suka dengan katakata lu seperti itu."

Konteks Tutur: tuturan ditutrkan oleh Deddy dalam podcast untuk menyanggah argumen Nadiem.

Tuturan tersebut berfungsi menjelaskan, bahwa Deddy mengakui tepatnya argumen Nadiem.

\section{Melaporkan}

Tindak tutur representatif melaporkan yang dituturkan oleh penutur memiliki sifat reportase, yaitu dalam penyampaian informasi terkesan subyektif, dan menurut anggapan pribadi si penutur.

(1) Deddy :'Jadi setelah gua mengatakan kuliah tidak penting at the end gua mengatakan ya penting."

Konteks Tutur: tuturan tersebut dituturkan oleh Deddy secara lisan dalam podcast, ia beranggapan secara subjektif bahwa kuliah tidak penting, namun argumennya berubah menjadi kuliah itu penting.

Tuturan tersebut berfungsi melaporkan, penyampaian informasi Deddy yang terkesan subjektif dalam argumennya.

\section{Menunjukkan}

Tindak tutur representatif yang ke-5 yaitu menunjukkan, bersifat memberikan bukti dari penutur ke pada mitra tutur, hal ini dilakukan akibat ketidakpercayaan mitra tutur sehingga penutur perlu menunjukkan bukti.

(1) Nadiem :'Tapi kenapa penting untuk dia pelajari? Penting karena dia datang ke situ untuk pertama kalinya anak saya mengetahui "oh ternyata ada mainan yang bukan punya saya, oh ternyata disini saya sama aja sama anak-anak lain ada aturan-aturan lain (social learning) belajar bersosialisasi, belajar

Konteks Tutur: tuturan tersebut dituturkan oleh Nadiem secara lisan dalam podcast, ia menunjukkan seberapa penting sekolah/kuliah (pendidikan) itu dalam argumen tersebut, di contohkan dengan anaknya berumur 2 tahun yang bersekolah PAUD.

Tuturan tersebut berfungsi menunjukkan pentingnya sekolah, walaupun usia dini sekalipun, dicontohkan dengan anaknya yang berusia 2 tahun sekolah PAUD, mengetahui untuk pertama kalinya ada barang yang bukan haknya, mengetahui lingkungan baru (dalam sekolah tersebut). Social experiment sangat penting diajarkan sejak dini, dalam argumen ini, Nadiem menunjukkan pentingnya sekolah dilaksanakan dengan sebaik-baiknya. 


\section{Menyebutkan}

Tindak tutur representatif menyebutkan memiliki sifat seenaknya. $\mathrm{Si}$ penutur menyebutkan poin-poin pokok informasi, cenderung seenaknya memaksa mitra tutur memahami informasi yang disampaikan oleh penutur tanpa penjelasan secara keseluruhan.

(1) Nadiem :'Mengenai bagaimana mengubah mindset-mindset masyarakat, dan itu suatu program yang sangat besar sekali yang akan kita lakukan juga untuk menyerang intoleransi, bulliying dll."

Konteks Tutur: tuturan tersebut dituturkan oleh Nadiem secara lisan dalam podcast, ia menyebutkan bagaimana cara-cara untuk mengubah mindset masyarakat, untuk menyerang berbagai macam permasalahan, seperti intoleransi dan bullying.

Tuturan tersebut berfungsi menyebutkan, yang memaksa mitra tutur percaya pada argumennya, dan di saat yang bersamaan penutur dengan seenaknya memaksa mitra tutur menerima serta memahami informasi dari penutur tanpa penjelasan secara keseluruhan.

(2) Deddy :".....di dalamnya kamu bisa belajar tentang kepemimpinan, projekprojek yang seru sama temen-temen kamu, kemampuan presentasi, dan softskill yang jauh lebih penting daripada kamu fokus pada kurikulum yang tidak relevan pada dunia nyata."
Konteks Tutur: tuturan tersebut dituturkan oleh Deddy secara lisan dalam podcast, ia menyebutkan pentingnya berorganisasi, di dalam organisasi kita bisa belajar tentang kepemimpinan, softskill-softskill tidak akan didapatkan dalam perkuliahan di kelas.

Tuturan tersebut berfungsi menyebutkan, yang memaksa mitra tutur percaya pada argumennya, dan di saat yang bersamaan penutur dengan seenaknya memaksa mitra tutur menerima serta memahami informasi dari penutur tanpa penjelasan secara keseluruhan.

\section{Memberikan}

Tindak tutur memberikan contoh memaksa si mitra tutur mempercayai informasi yang diucapkan oleh si penutur.

(1) Deddy :"Contohnya bahwa sekolah penting nggak ya ada banyak hal, pertama ketika lu lulus S1 orang kadang ngelakuin apa yang namanya postponing reality. Postponing reality dia lulus S1, dia ngga tau mau kerja apa."

Konteks Tutur: tuturan tersebut dituturkan oleh Deddy secara lisan dalam podcast, ia memberikan contoh argumen-argumen pendukung tidak pentingnya pelajaran di sekolah.

Tuturan tersebut berfungsi memberikan contoh memaksa si mitra tutur mempercayai informasi yang diucapkan oleh si penutur. 


\section{Kesaksian}

Tidak ditemukan tindak tutur representatif kesaksian dalam podcast ini.

\section{Berspekulasi}

Tindak tutur representatif berspekulasi yang dituturkan oleh si penutur memiliki sifat tidak valid, dan dapat memiliki potensi tidak sesuai dengan fakta.

(1) Nadiem :"Memang berat, dan mungkin butuh waktu 5-15 tahun, jadi ini akan melewati masa saya."

Konteks Tutur: tuturan tersebut dituturkan oleh Nadiem secara lisan dalam podcast, ia berspekulasi tentang argumennya.

Tuturan tersebut berfungsi menjelaskan spekulasi Nadiem bahwa apa yang dilakukannya sebagai Menteri Pendidikan terbilang berat, ia berspekulasi waktu terlaksana secara maksimum antara 5-15 tahun, melewati masa jabatannya.

\section{SIMPULAN}

Dalam hasil penelitian ini, penulis menemukan jenis-jenis tindak tutur representatif diantaranya:

(1) menyatakan, (2) menuntut, (3) mengakui, (4) melaporkan, (5) menunjukkan, (6) menyebutkan, (7) memberikan, (8) kesaksian, dan (9) berspekulasi. Dari video podcast berdurasi 10 menit 56 detik memuat 16 data yang termasuk kepada tindak tutur representatif, di antaranya:
1. Tindak tutur representatif akan terjadi jika mitra tutur terikat pada argumen penutur, sehingga mempercayai kebenaran informasi dari penutur.

2. Inti dari jenis-jenis tindak tutur representatif yaitu : tindak tutur menyatakan bersifat subjektif, tindak tutur menuntut bersifat memaksa, tindak tutur mengakui bersifat pengakuan, tindak tutur melaporkan bersifat reportase, tindak tutur menunjukkan bersifat memberikan bukti, tindak tutur menyebutkan bersifat seenaknya, tindak tutur memberikan bersifat memberikan contoh, tindak tutur kesaksian bersifat penegas, dan tindak tutur berspekulasi bersifat tidak sahih.

3. Dari 16 data di atas, dengan penjabaran, yang termasuk kedalam:

tindak tutur menyatakan berjumlah 2 , tindak tutur menuntut berjumlah 3 , tindak tutur mengakui berjumlah 4, tindak tutur melaporkan berjumlah 1, tindak tutur menunjukkan berjumlah 1 , tindak tutur menyebutkan berjumlah 2 , tindak tutur memberikan berjumlah 1 , tindak tutur kesaksian tidak ada (-), tindak tutur berspekulasi berjumlah 1 .

\section{SARAN}

Untuk penelitian selanjutnya penulis berharap lebih dipertegas lagi sekat-sekat pembeda antara ke-9 tindak tutur representatif yang 
mencakup (1) menyatakan, (2) menuntut, (3) mengakui, (4) melaporkan, (5) menunjukkan, (6) menyebutkan, (7) memberikan, keaksian, dan (9) berspekulasi. Sehingga penulis berharap penelitian selanjutnya bisa lebih memahamkan pembaca terkait hakikat dan analisis tindak tutur representatif dan meminimalisasi kerancuan pikir pembaca.

\section{DAFTAR PUSTAKA}

Rustono. 1999. Pokok-Pokok Pragmatik. Semarang: CV. IKIP Semarang Press. Leech, Geoffrey. 2011. Prinsip-Prinsip Pragmatik. Jakarta: Penerbit Universitas Indonesia.

Gultom, Meri Kristina. (2011). Tindak Tutur Ilokusi Dalam Novel Tanah Tabu Karya Anindita S. Thayf. Skripsi. Fakultas Ilmu Budaya Universitas Sumatera Utara.

Handayani, Puji. (2012). Realisasi Tindak Tutur Representatif Dan Direktif Guru Dan Anak Didik Di Tk 02 Jatiwarno, Kecamatan Jatipuro, Kabupaten Karangannyar. Skripsi. Program Studi Pendidikan Bahasa Sastra Indonesia dan Daerah Fakultas Keguruan Dan Ilmu Pendidikan Universitas Muhammadiyah Surakarta.

Yusri, dkk. (2012). Representasi Tindak Tutur Calon Gubernur Sulawesi Selatan: Analisis Wacana Kesopanan Berbahasa. Jurnal MAKARA Sosial Humaniora, 16(2), 116-122.

Pramesti, Swesti Intan. (2013). Tindak Tutur Representatif Dalam Film Le Fabuleux Destin D'amélie Poulain
Karya Jean Pierre Jeunet Dan Guillaume Laurant. Skripsi. Jurusan Pendidikan Bahasa Prancis Fakultas Bahasa Dan Seni Universitas Negeri Yogyakarta 2013.

Rahayuningsih, Eka. (2013). Tindak Tutur Representatif Dalam Ceramah K.H. Anwar Zahid. Skripsi. Program Studi Pendidikan Bahasa Dan Sastra Indonesia Jurusan Pendidikan Bahasa Dan Seni Fakultas Keguruan Dan Ilmu Pendidikan Universitas Jember.

Ellini, Mefi, dkk. (2014). Tindak Tutur Ilokusi Ustaz Yusuf Mansur Dalam Acara Wisata Hati Di Stasiun Televisi Antv. Skripsi. Fakultas Bahasa dan Seni Universitas Negeri Padang.

R, Zulfira Hildana. (2014). Tindak Tutur Ilokusi Representatif Dalam Komik Seratoes Ploes Aspirasi Karya Haryadhi: Sebuah Kajian Pragmatik. Journal Unair, 2(2), 146-157.

Rahma, Anis Nurulita. (2014). Analisis Tindak Tutur Ilokusi Dalam Dialog Film Animasi Meraih Mimpi. Journal Unair, 2(2), 1-15.

Awram, Pezi. (2014). Analisis Tindak Tutur Ilokusi Dalam Novel Negeri 5 Menara Karya Ahmad Fuadi. Skripsi. Fakultas Keguruan Dan Ilmu Pendidikan Universitas Bengkulu.

Astuti, Sri Budi dan Retnosari, Ira Eko. (2016). Tindak Tutur Dalam Talkshow Hitam Putih di Trans 7. Jurnal EduKata, 3(2), 104-105.

Hapsari, Paramita Widya dkk. (2016). Kajian Terjemahan Kalimat Yang 
Merepresentasikan Tindak Tutur Asertif Menjawab Dalam Dua Versi Terjemahan Novel Pride And Prejudice. Jurnal ResearchGate, 121131.

Lestari, Sri Ayu, dkk. (2016). Analisis Tindak Tutur Antara Penjual Dan Pembeli di Pasar Sentral Watampone Maros Kabupaten Bone (Kajian Pragmatik). Jurnal Eprints (utuk thesis).Universtas Negeri Makassar.

Noviana, Dinda. (2017). Tindak Tutur Representatif Dalam Rubrik Opini Surat Kabar Kompas Edisi Maret 2017 Sebagai Alternatif Bahan Ajar Bahasa Indonesia di SMA. Skripsi. Program Studi Pendidikan Bahasa Indonesia Fakultas Keguruan Dan Ilmu Pendidikan Universitas Muhammadiyah Surakarta.

Maysaroh, Suyalik, dkk. (2017). Tindak Tutur Representatif Dalam Status Facebook. Junal online mahasiswa Fakultas Keguruan dan Ilmu Pendidikan Universitas Riau.

Hartati, Yulia Sri. (2018). Tindak Tutur Asertif Dalam Gelar Wicara Mata Najwa Di Metro TV. Jurnal KATA, 2(2), 296-302.

Safriani Novi, dkk. (2018). Tindak Tutur Asertif Dalam Novel Perempuan Terpasung Karya Hani Naqshabandi. Jurnal Ilmiah Mahasiswa Jurusan PBSI, 3(1), 70-75.

Utami, Muniroh Putri. (2019). Tindak Tutur Representatif Pada Tajuk Rencana Dalam Surat Kabar Solopos Edisi
Januari 2019. Skripsi. Jurusan Pendidikan Bahasa Indonesia Fakultas Keguruan Dan Ilmu Pendidikan Universitas Muhammadiyah Surakarta.

Habib, Ahmad Farhan. (2019). Pengaruh Kesenjangan Kepuasan Terhadap Kepuasan Mendengar Dan Keberlanjutan Mendengarkan Podcast(Analisis Kuantitatif Pengaruh Kesenjangan Kepuasan Terhadap Kepuasan Mendengar Dan Intensi Keberlanjutan Mendengarkan Podcast Melalui Spotify Yang Dimoderasi Kebiasaan Mendengarkan Podcast Di Kalangan Mahasiswa Universitas Sebelas Maret Tahun 2019). Jurnal untuk skripsi. Program Studi Ilmu Komunikasi Fakultas Ilmu Sosial dan PolitikUniversitas Sebelas Maret.

Yunus, Muhammaad (2019). Tindak Tutur Interaksi Jual Beli di Pasar Lama Banjarmasin. Journal umbjm, 1(1), $17-18$

Nuamila. (2020). Tindak Tutur Tokoh Ayah dan Tokoh Angel Dalam Film "Ayah, Mengapa Aku Berbeda?".Jurnal Sinestesia, 10(1), 49-53.

Zaen Izah Azizah, dkk. (2020). Modus Tindak Tutur Representatif Pada Ceramah Ustaz Maulana "Acara Islam Itu Indah". Jurnal lppmunindra, 12(1), $32-43$.

Wulansafitri, Inayah dan Syaifudin Ahmad. (2020). Kesantunan Berbahasa Dalam Tuturan Film My Stupid Boss 1. Journal Sastra Indonesia, 9(1), 21-25. 
BAHTERA INDONESIA:

ISSN 2541-3252

Jurnal Penelitian Pendidikan Bahasa dan Sastra Indonesia

Vol. 5, No. 2 Sep. 2020

Deddy Corbuzier. (2020, Maret 8). Top searches

https://www.youtube.com/watch?v=RO

on Youtube: Match-Jully [Berkas video].

$\underline{-R B S f x Z O M \& t=2 s}$

Diakses

dari 